\title{
Antioxidant Substances and Trace Element Content in Macroalgae from a Subtropical Lagoon in the West Coast of the Baja California Peninsula
}

\section{Paola A. Tenorio Rodriguez'1, LC Méndez-Rodríguez¹, E Serviere-Zaragoza² ${ }^{\text {T O’Hara }}{ }^{3}$ and T Zenteno-Savín ${ }^{1 *}$}

${ }^{1}$ Planeación Ambiental y Conservación, Centro de Investigaciones Biológicas del Noroeste, S. C., La Paz, Baja California Sur, México ${ }^{2}$ Ecología Pesquera, Centro de Investigaciones Biológicas del Noroeste, S.C., La Paz, Baja California Sur, México

${ }^{3}$ Department of Biology and Wildlife, University of Alaska Fairbanks, Fairbanks, USA

\begin{abstract}
Macroalgae play an important role in the ecology of the marine environment. They form the base of the food webs, and represent the major food source for a variety of organisms. In order to assess their potential nutritional value, the antioxidant and trace element content (vitamin $\mathrm{C}$, total polyphenols, zinc, iron, cooper, selenium, cadmium and lead) of eight macroalgae species, three red (Hypnea spinella, Gracilaria textorii and G. vermicullophyla), four green (Caulerpa sertularioides, Codium simulans, C. amplivesiculatum and Ulva lactuca) and one brown (Dictyota flabellata) macroalgae, were determined. The concentration ranges found were as follows: zinc, 19.1-7.4; iron, 638.4-89.2; copper, 3.9-0.9; selenium, 0.32-10; cadmium, 4.33-0.02, and lead 8.8-0.39 mg kg-1 dry weight. Green macroalgae showed higher concentrations of iron and zinc. Total polyphenol content ranged from 29.6 to $70.3 \mathrm{mg} 100$ $\mathrm{g}^{-1}$ dry weight; brown macroalgae showed higher polyphenol concentration. C. simulans and $C$. amplivesiculatum had higher vitamin $C$ content $\left(3.16 \pm 0.52 \mathrm{mg} \mathrm{g}^{-1}\right.$ and $6.08 \pm 0.69 \mathrm{mg} \mathrm{g}^{-1}$ dry weight, respectively) than the other species. Comparison with several commonly consumed vegetables and fruits suggest that these macroalgae are likely a good alternative source of antioxidants and micronutrients for consumers.
\end{abstract}

Keywords: Antioxidants; Macroalgae; Micronutrients; Polyphenols; Trace elements; Vitamin C

Abbreviations: ROS: Reactive oxygen species; LDL: Low density lipoproteins; $\mathrm{O}_{2}{ }^{--}$: Superoxide radical; $\mathrm{H}_{2} \mathrm{O}_{2}$ : Hydrogen peroxide; $\mathrm{OH}{ }^{*}$ : Hydroxyl radical; ${ }^{1} \mathrm{O}_{2}$ : Singlet oxygen; $\mathrm{Cu}$ : Copper; Fe: Iron; Pb: Lead; Cd: Cadmium; Zn: Zinc; Se: Selenium; GAE: Gallic acid equivalents; FAO/WHO: Food and Agriculture Organization/World Health Organization; RNI: Recommended nutrient intake

\section{Introduction}

In many countries, fresh marine macroalgae are used as food by coastal communities, and considered as a traditional food item due to their nutritional value and characteristic taste [1-3]. Macroalgae are valuable sources of proteins, polysaccharides, and fiber; but they are also rich in antioxidants and micronutrients, such as vitamins and trace elements [4-6].

Antioxidant vitamins and trace elements are usually obtained from the diet, since some organisms are unable to synthesize them. The beneficial effects of antioxidants are due to their capacity to scavenge and neutralize reactive oxygen species (ROS) [7]. An excessive ROS production and/or low antioxidant defense can cause oxidative damage to biomolecules, such as proteins, lipids and DNA [8,9]. Antioxidants may reduce ROS production by scavenging free radicals through various mechanisms $[7,10]$. Some trace elements contribute to the function of endogenous antioxidant enzymes by acting as cofactors [11,12]. Most polyphenols can act as chain breakers or radical scavengers and prevent the oxidation of low density lipoproteins (LDL) [12,13]. Vitamin C is a scavenger against superoxide radical $\left(\mathrm{O}_{2}{ }^{-}\right)$, hydrogen peroxide $\left(\mathrm{H}_{2} \mathrm{O}_{2}\right)$, hydroxyl radical $\left(\mathrm{OH}^{\circ}\right)$, and singlet oxygen $\left({ }^{1} \mathrm{O}_{2}\right)$, which would otherwise react to form lipid peroxides; vitamin $\mathrm{C}$ also reduces the tocopheroxyl radical formed by interaction of $\alpha$-tocopherol with lipid peroxides in cell membranes $[7,14]$. This demonstrates the wide variety of reactive intermediates vitamin $\mathrm{C}$ interacts with, to maintain the function of cellular components.

Marine macroalgae are a potentially good source of micronutrients and may be beneficial for human health, given their reportedly high vitamin and trace element content $[1,15,16]$. Most published studies on macroalgae are focused on ecological aspects and chemical composition (protein, carbohydrate, ash and calories). However, little is known about macroalgae antioxidant vitamins and micronutrient composition $[5,17,18]$. The objective of this study was to assess the antioxidant vitamin and trace element content of eight macroalgae species, from a subtropical and unpolluted lagoon in the west coast of the Baja California peninsula. Lead and cadmium concentrations were also assessed, given their toxicological potential. This information may be useful in the search for alternative and supplementary food items in the Baja California peninsula.

\section{Materials and Methods}

Eight species of macroalgae belonging to the Chlorophyta, Rhodophyta and Ochrophyta Pheaophyceae divisions were collected from Bahia Magdalena, Baja California Sur, Mexico $\left(24^{\circ} 15^{\prime} \mathrm{N}\right.$ and $25^{\circ} 20^{\prime} \mathrm{N}$ and $111^{\circ} 30^{\prime} \mathrm{W}$ and $112^{\circ} 15^{\prime} \mathrm{W}$ ). Bahia Magdalena is a shallow lagoon with high productivity resulting from seasonal marine upwelling [19]. Macroalgae were collected in November of 2009, February, April and June of 2010. Samples were carried on ice, stored in black bags to the laboratory, where macroalgae were washed with filtered, cold seawater to remove all epiphytes and other debris. The samples used for trace element analyses were dried in an oven at $60^{\circ} \mathrm{C}$ for $48 \mathrm{~h}$. The dried samples were then ground into a fine powder using a coffee grinder, and stored until analyzed. Dried samples destined for copper $(\mathrm{Cu})$, iron $(\mathrm{Fe})$, lead $(\mathrm{Pb})$, cadmium $(\mathrm{Cd})$ and zinc $(\mathrm{Zn})$ analyses were digested in

*Corresponding author: T Zenteno-Savín, Planeación Ambiental y Conservación Centro de Investigaciones Biológicas del Noroeste, S.C., Instituto Politécnico Nacional 195, Playa Palo de Santa Rita Sur, La Paz, Baja California Sur, C.P. 23096, Mexico, E-mail: tzenteno04@cibnor.mx

Received November 12, 2012; Accepted November 24, 2012; Published November 26, 2012

Citation: Tenorio-Rodríguez PA, Méndez-Rodríguez LC, Serviere-Zaragoza E O’Hara T, Zenteno-Savín T (2013) Antioxidant Substances and Trace Element Content in Macroalgae from a Subtropical Lagoon in the West Coast of the Baja California Peninsula. Vitam Trace Elem 2:108.

Copyright: () 2013 Zenteno-Savín T, et al. This is an open-access article distributed under the terms of the Creative Commons Attribution License, which permits unrestricted use, distribution, and reproduction in any medium, provided the original author and source are credited. 
Citation: Tenorio-Rodríguez PA, Méndez-Rodríguez LC, Serviere-Zaragoza E, O’Hara T, Zenteno-Savín T (2013) Antioxidant Substances and Trace Element Content in Macroalgae from a Subtropical Lagoon in the West Coast of the Baja California Peninsula. Vitam Trace Elem 2:108.

Page 2 of 5

acid-washed Teflon tubes, with concentrated nitric acid $\left(\mathrm{HNO}_{3}\right)$ in a microwave oven (Mars 5X, CEM, Matthew, NC, USA), and analyzed by atomic absorption (GBC Scientific equipment, AVANTA, Dandegong, Australia), using an air-acetylene flame. Selenium (Se) determinations were performed at the Wildlife Toxicology Laboratory, University of Alaska Fairbanks. Samples were digested twice, first with $\mathrm{HNO}_{3}$, and then with $\mathrm{HCl}(37 \%)$ in a microwave (3000 Microwave Multiwave Sample Preparation System, Anton Para, Austria). Se concentration was analyzed by atomic absorption spectrometry (AAnalyst 800 PerkinElmer Instruments, Shelton, CT, USA), with a flow injection system, according to the procedure described by Knott et al. [20] and Barrera-García et al. [21]. The results are expressed in $\mathrm{mg} \mathrm{kg}^{-1}$ dry weight (d.w.).

The vitamin C (L-ascrobic acid) content of macroalgae was determined by high-performance liquid chromatography (HPLC, Waters, Milford, MA, USA) [22,23]. Each sample $(0.1 \mathrm{~g})$ was homogenized with metaphosporic acid ( $3 \% \mathrm{w} / \mathrm{v})$, incubated for $40 \mathrm{~min}$ at $4^{\circ} \mathrm{C}$ in the dark and centrifuged for $15 \mathrm{~min}$ at $23,985 \mathrm{~g}$ at $4^{\circ} \mathrm{C}$. Samples were then filtered through a $0.45 \mu \mathrm{m}$ filter prior to injection. Ten $\mu \mathrm{L}$ of each sample were injected into the HPLC. The mobile phase was a mixture of water, sulfuric acid ( $\mathrm{pH} 2.4$ ), and acetonitrile (100\%, HPLC grade). The flow rate was $1 \mathrm{~mL}$ min-1, and the detection wavelength was set at $245 \mathrm{~nm}$. The results are expressed in $\mathrm{mg}$ vitamin $\mathrm{C} \mathrm{g}^{-1}$ d.w.

The Folin-Ciocalteu colorimetric method, with modifications, was used to quantify total polyphenol concentration in macroalgae samples [24,25]. Briefly, $1 \mathrm{~g}$ of fresh sample was ground with a mixture of water:methanol:acetone $(2: 3: 5 \mathrm{v} / \mathrm{v})$, using a mortar and pestle over ice. Samples were incubated in a water bath at $65^{\circ} \mathrm{C}$ with agitation for $1 \mathrm{~h}$. Extracts were centrifuged at 15,292 g for $10 \mathrm{~min}$, and the supernatant was collected. $\mathrm{Na}_{2} \mathrm{CO}_{3}$ was added and samples were incubated for 1 $\mathrm{h}$ at room temperature. The absorbance at $750 \mathrm{~nm}$ was recorded in a microplate reader (BioRad ${ }^{\mathrm{TM}} 550$, Hercules, CA, USA), and compared to a gallic acid calibration curve. The results are expressed as gallic acid

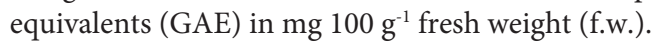

Normality and homogeneity of variance were determined by using Shapiro-Wilks and Bartlett tests. All variables were log-transformed in order to normalize the data. Differences between groups and species were analyzed by using ANOVA or Student t-tests, with Tukey posthoc tests [26]. Results are expressed as mean \pm SE, and differences were considered statistically significant at $\mathrm{p}<0.05$ level. Statistica 8.0 (StatSoft Inc. Tulsa, OK, USA) software was used to perform all statistical analyses.

\section{Results}

The trace element content of eight macroalgae species is shown in table 1 . Fe concentration in all macroalgae species studied ranged from 89.2 to $638.4 \mathrm{mg} \mathrm{kg}^{-1} \mathrm{~d}$.w. Green macroalgae had the highest $\mathrm{Fe}$ content ( $\mathrm{p}=0.013)$, with C. simulans and C. amplivesiculatum showing the highest values. Zn levels ranged from $7.4 \mathrm{mg} \mathrm{kg}^{-1} \mathrm{~d}$.w. in $H$. spinella to $19.1 \mathrm{mg} \mathrm{kg}^{-1} \mathrm{~d}$.w. in $\mathrm{U}$. lactuca. $\mathrm{Cu}$ concentrations ranged from 0.9 $\mathrm{mg} \mathrm{kg}^{-1}$ in H. spinella to $3.9 \mathrm{mg} \mathrm{kg}^{-1}$ in C. sertularioides. Se, $\mathrm{Cd}$ and $\mathrm{Pb}$ levels ranged between $0.10-0.32 \mathrm{mg} \mathrm{kg}^{-1}, 0.01-4.33 \mathrm{mg} \mathrm{kg}^{-1}$, and $8.8-0.54$ $\mathrm{mg} \mathrm{kg}^{-1}$, respectively (Table 1 ). No differences in trace element content were found between groups or among species.

The mean content of total polyphenols in all macroalgae species studied, ranged from 29.6 to $70.3 \mathrm{mg}$ of GAE $100 \mathrm{~g}^{-1}$ w.w. (Figure 1). Total polyphenol content was higher in green and brown macroalgae, compared to red macroalgae $(\mathrm{p}=0.00002)$. In general, the brown macroalga $D$. flabellata and the green macroalga $C$. sertularioides had higher total polyphenol concentrations, in comparison with the rest of the species $\left(70.3 \pm 7.6\right.$ and $68.6 \pm 6.03 \mathrm{mg}$ of GAE $100 \mathrm{~g}^{-1}$ w.w. respectively). $U$. lactuca had the lowest total polyphenol content $(29.6$ $\pm 1.5 \mathrm{mg}$ of GAE $100 \mathrm{~g}^{-1}$ w.w.).

Vitamin C concentration in eight macroalgae species from Bahia Magdalena, Baja California Sur is shown in figure 2. Vitamin C content in all macroalgae species analyzed ranged from 1.24 to $6.08 \mathrm{mg} \mathrm{g}^{-1} \mathrm{~d} . \mathrm{w}$. Vitamin $\mathrm{C}$ concentration was higher in green and brown macroalgae, compared to red macroalgae $(p=0.002)$. The highest vitamin $C$ concentration was found in the green macroalga $C$. amplivesiculatum $\left(6.08 \pm 0.69 \mathrm{mg} \mathrm{g}^{-1}\right.$ d.w. $)(\mathrm{p}=0.001)$, while the red macroalga H. spinella had the lowest vitamin $\mathrm{C}$ content $\left(1.24 \pm 0.16 \mathrm{mg} \mathrm{g}^{-1} \mathrm{~d}\right.$.w.).

\section{Discussion}

The majority of the essential minerals and trace elements needed for human nutrition can be found in macroalgae; therefore, macroalgae could be regarded as a valuable resource. Trace elements such as Fe, $\mathrm{Cu}$ and $\mathrm{Se}$ are considered essential for biological processes, including growth, reproduction, hormone metabolism and antioxidant defense [27-29]. Cd and $\mathrm{Pb}$ are a potential health hazard and are commonly measured, as indicators of environmental pollution [30,31]. All macroalgae species analyzed in the present study showed lower concentrations of $\mathrm{Cd}$ than previously reported $\left(0.71 \mathrm{mg} \mathrm{kg}^{-1}\right.$ [32]; $1.9 \mathrm{mg} \mathrm{kg}^{-1}$ [31]; $3.70 \mathrm{mg} \mathrm{kg}^{-1}$ [33]; $4.8 \mathrm{mg} \mathrm{kg}^{-1}$ [34]). The mean $\mathrm{Pb}$ concentration in macroalgae species analyzed was $3.46 \mathrm{mg} \mathrm{kg}^{-1}$. Similar $\mathrm{Pb}$ concentrations were reported for macroalgae $\left(3.50 \mathrm{mg} \mathrm{kg}^{-1}\right.$ [33], and

\begin{tabular}{|c|c|c|c|c|c|c|c|}
\hline Species & $\mathrm{n}$ & $\mathrm{Zn}$ & $\mathrm{Fe}$ & $\mathrm{Cu}$ & $\mathrm{Se}$ & $\mathrm{Cd}$ & $\mathrm{Pb}$ \\
\hline $\begin{array}{l}\text { Chlorophyta } \\
\text { Caulerpa sertularioides (S.G. Gmelin) M.A. Howe }\end{array}$ & 5 & $16.8 \pm 3.9$ & $420.9 \pm 107.9$ & $3.9 \pm 1.84$ & $0.32 \pm 0.09$ & $0.38 \pm 0.18$ & $2.71 \pm 1.01$ \\
\hline $\begin{array}{l}\text { Codium amplivesiculatum } \\
\text { Setchell \& N.L. Gardner }\end{array}$ & 3 & $17.1 \pm 4.9$ & $638.4 \pm 176.4$ & $2.2 \pm 0.66$ & $0.19 \pm 0.07$ & $0.02 \pm 0.00$ & $0.39 \pm 0.28$ \\
\hline Codium simulans Setchell \& N.L. Gardner & 5 & $18.2 \pm 6.5$ & $447.6 \pm 176.7$ & $1.7 \pm 0.52$ & $0.19 \pm 0.01$ & $1.11 \pm 0.39$ & $8.28 \pm 2.44$ \\
\hline Ulva lactuca Linnaeus & 3 & $19.1 \pm 7.5$ & $213.1 \pm 72.3$ & $2.3 \pm 2.2$ & $0.11 \pm 0.04$ & $0.02 \pm 0.01$ & $1.68 \pm 0.46$ \\
\hline $\begin{array}{l}\text { Ochrophyta-Phaeophyceae } \\
\text { Dictyota flabellata (F.S.Collins) Setchell \& N.L.Gardner* }\end{array}$ & 2 & 14.0 & 560.1 & 2.0 & & 4.33 & 8.8 \\
\hline $\begin{array}{l}\text { Rhodophyta } \\
\text { Gracilaria vermiculophylla } \\
\text { (Ohmi) Papenfus }\end{array}$ & 7 & $12.2 \pm 4.8$ & $190.3 \pm 51.5$ & $1.0 \pm 0.41$ & $0.10 \pm 0.02$ & $0.10 \pm 0.09$ & $2.25 \pm 1.05$ \\
\hline Gracilaria textorii (Suringar) De Toni & 4 & $15.8 \pm 4.3$ & $89.2 \pm 24.4$ & $1.2 \pm 0.18$ & $0.15 \pm 0.01$ & $1.09 \pm 0.54$ & $1.47 \pm 0.77$ \\
\hline Hypnea spinella (C. Agardh) Kützing & 3 & $7.4 \pm 0.21$ & $409.6 \pm 27.2$ & $0.9 \pm 0.05$ & $0.10 \pm 0.01$ & $1.01^{*}$ & $2.1^{*}$ \\
\hline
\end{tabular}

Mean values \pm standard error

*Standard error not calculated

Table 1: Trace element concentrations $\left(\mathrm{mg} \mathrm{kg}^{-1}\right)$ in macroalgae species from Bahia Magdalena, Baja California Sur, Mexico. 
Citation: Tenorio-Rodríguez PA, Méndez-Rodríguez LC, Serviere-Zaragoza E, O’Hara T, Zenteno-Savín T (2013) Antioxidant Substances and Trace Element Content in Macroalgae from a Subtropical Lagoon in the West Coast of the Baja California Peninsula. Vitam Trace Elem 2:108.

Page 3 of 5

$2.84 \mathrm{mg} \mathrm{kg}^{-1}$ [35]); however, Mok et al. [36] reported lower Pb levels $\left(0.89 \mathrm{mg} \mathrm{kg}^{-1}\right)$. Se content in macroalgae has been reported to be in the range of 0.1-6 $\mu \mathrm{g} \mathrm{g}^{-1}$ [32], which is similar to what was found in the present study. Concentrations of trace elements similar or lower than those found in eight species of macroalgae in this study have been reported for vegetables: $323 \mu \mathrm{g} \mathrm{Fe} \mathrm{{ } ^ { - 1 }}$ in lettuce, $182.8 \mu \mathrm{g} \mathrm{Fe} \mathrm{g}^{-1}$ in parsley, $166.4 \mu \mathrm{g} \mathrm{Fe} \mathrm{g}^{-1}$ in spinach [37], 1.02-0.33 $\mathrm{mg} \mathrm{Cu} \mathrm{kg}^{-1}$ in spinach, and 1.11-0.51 mg Cu kg-1 in tomato [38]. The concentrations of these elements in macroalgae depend on the surrounding environment. Natural enrichment of trace elements in the Baja California peninsula has been suggested to occur due to natural phenomena, such as currents, upwelling and various geological sources [39,40].

Concentrations of vitamin $\mathrm{C}$ in most of the analyzed macroalgae species in this study were similar or higher than those reported for congeneric species in Hawaii $\left(3.0,2.2\right.$, and $1.3 \mathrm{mg} \mathrm{g}^{-1}$ d.w. in Ulva

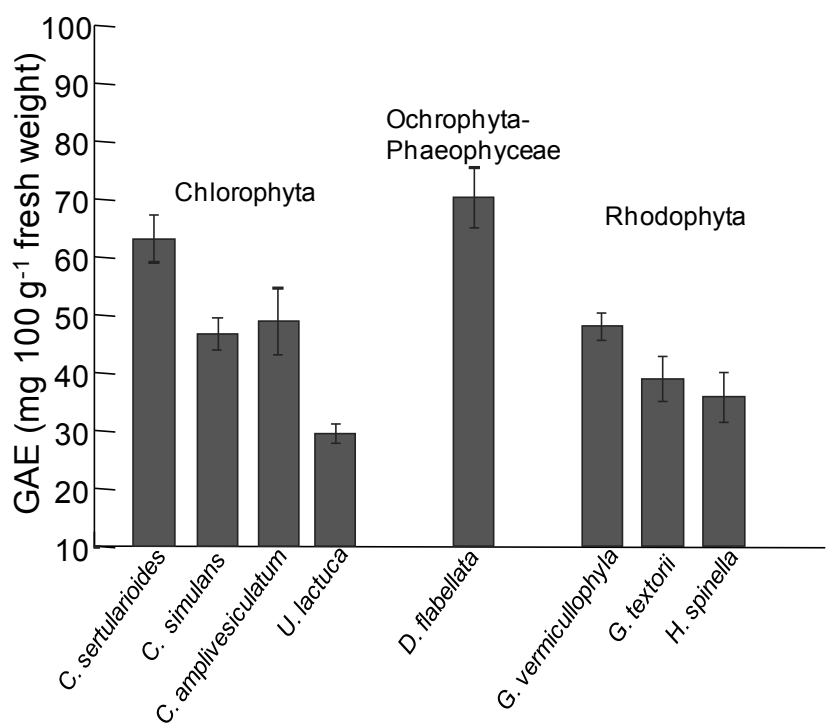

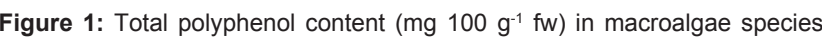
from Bahia Magdalena, Baja California Sur, Mexico, grouped by division. Data are presented as mean \pm SE.

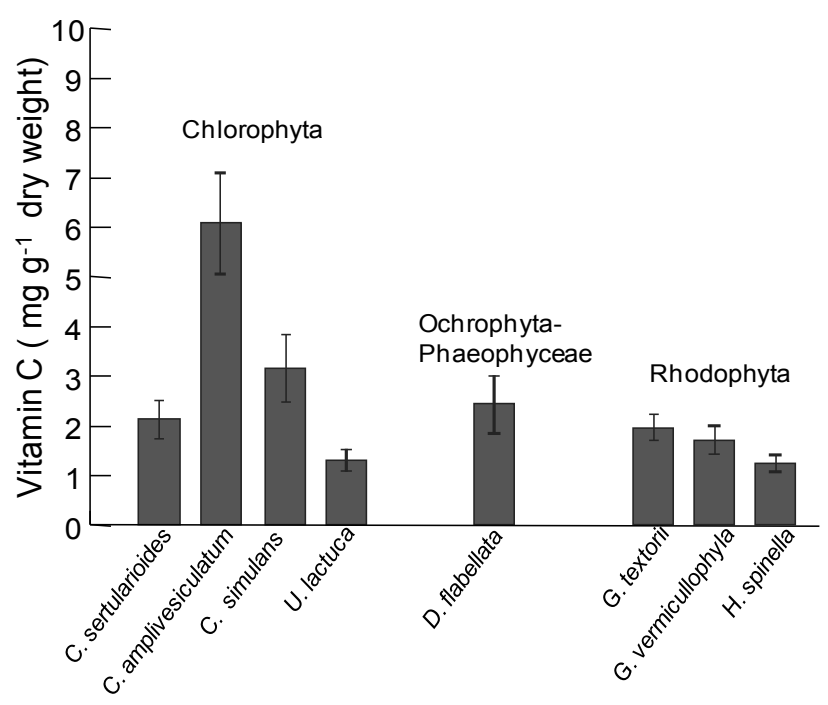

Figure 2: Vitamin $\mathrm{C}$ content $\left(\mathrm{mg} \mathrm{g}^{-1} \mathrm{dw}\right)$ in macroalgae species from Bahia Magdalena, Baja California Sur, Mexico, grouped by division. Data are presented as mean \pm SE.

\begin{tabular}{|c|c|l|}
\hline Micronutrient & $\begin{array}{c}\text { Recommended } \\
\text { daily intake }\end{array}$ & Reference \\
\hline $\mathrm{Fe}$ & $48 \mathrm{mg}$ & $\begin{array}{l}\text { Joint FAO/WHO Expert Committee on Food } \\
\text { Additives, 1999 }\end{array}$ \\
\hline $\mathrm{Cu}$ & $3 \mathrm{mg}$ & $\begin{array}{l}\text { Joint FAO/WHO Expert Committee on Food } \\
\text { Additives, } 1999\end{array}$ \\
\hline $\mathrm{Zn}$ & $60 \mathrm{mg}$ & Joint FAO/WHO Expert consultation 1998 \\
\hline $\mathrm{Se}$ & $29 \mu \mathrm{g}$ & Joint FAO/WHO Expert consultation 1998 \\
\hline $\mathrm{Cd}$ & $70 \mu \mathrm{g}$ & $\begin{array}{l}\text { Joint FAO/WHO Expert Committee on Food } \\
\text { Additives, } 1999\end{array}$ \\
\hline $\mathrm{Pb}$ & $214 \mu \mathrm{g}$ & $\begin{array}{l}\text { Joint FAO/WHO Expert Committee on Food } \\
\text { Additives, 1999 }\end{array}$ \\
\hline Vitamin C & $45 \mathrm{mg}$ & Joint FAO/WHO Expert consultation 1998 \\
\hline
\end{tabular}

Table 2: Recommended daily dose of trace elements and antioxidants.

flexuosa (as Enteromorpha flexuosa), Ulva fasciata and Monostroma oxyspermum, respectively, [5,41], along the coast of India $(0.00244 \mathrm{mg}$ $\mathrm{g}^{-1}$ d.w. in Ulva reticulate) [42], or the central part of the Baja California Peninsula (3.4 $\mathrm{mg} \mathrm{g}^{-1}$ d.w. in Eisenia arborea) [43]. However, the two Codium species analyzed in this study had higher vitamin $\mathrm{C}$ content (mean of $4.62 \mathrm{mg} \mathrm{g}^{-1}$ d.w.) than the values reported for other green macroalgae species $[5,44]$. Overall, vitamin $C$ concentrations in the macroalgae species analyzed in this study were comparable with those reported in guava $\left(1.44 \mathrm{mg} \mathrm{g}^{-1}\right)$, papaya $\left(1.08 \mathrm{mg} \mathrm{g}^{-1}\right)$ and red peppers $\left(1.51 \mathrm{mg} \mathrm{g}^{-1}\right)$, and were higher than in oranges $\left(0.67 \mathrm{mg} \mathrm{g}^{-1}\right)$, or broccoli $\left(0.89 \mathrm{mg} \mathrm{g}^{-1}\right)[45,46]$. The intake of vitamin $\mathrm{C}$ is essential since the human body is unable to synthesize it. It is effective in ameliorating symptoms of the common cold; moreover, evidence shows that vitamin $\mathrm{C}$ reduces mortality from heart disease, and can prevent oxidative stress in the process of immune response $[47,48]$.

Total poly phenol content in the brown macroalga $D$. flabellata and in the green macroalga $C$. sertularioides was higher than in other species analyzed in this study. Previous studies similarly reported that polyphenol content in brown marine algae is higher than that in red marine algae $[49,50]$. Phenolic compounds are widely distributed in all macroalgae. These compounds are good antioxidants, since they can act as metal chelators and ROS scavengers trapping the lipid alkoxyl radical preventing lipid peroxidation. The beneficial effects of polyphenols on human health and their contribution to protect against chronic diseases, such as neurodegenerative disorders and cancer, have been extensively documented [51,52]. In this study, total polyphenol content in the macroalgae species analyzed was higher than that reported for several vegetables and fruits, such as avocado (3.6 $\mathrm{mg} 100$ $\mathrm{g}^{-1}$ f.w.), kiwifruit (28.1 mg $100 \mathrm{~g}^{-1}$ f.w.), broccoli (98.9 mg $100 \mathrm{~g}^{-1}$ f.w.), pear (69.2 mg $100 \mathrm{~g}^{-1}$ f.w.), mango (68.1 $\mathrm{mg} 100 \mathrm{~g}^{-1}$ f.w.), and tomato (13.7 mg $100 \mathrm{~g}^{-1}$ f.w.) [53].

In order to evaluate the food safety of the analyzed samples, regulation in other countries was consulted, since Mexico has not yet adopted official trace element limits regarding macroalgae used for human consumption. Cd concentration in G. textorii, H. spinella, C. simulans and D. flabellata and $\mathrm{Pb}$ content in C. simulans and D. flabellata exceeded the permissible limit, considered by the French Legislation ( $0.5 \mathrm{mg} \mathrm{Cd} \mathrm{kg}^{-1}$ and $5 \mathrm{mg} \mathrm{Pb} \mathrm{kg}{ }^{-1}$ d.w.). However, the Food and Agriculture Organization/World Health Organization (FAO/ WHO) [54-56] have jointly recommended daily doses for trace elements and vitamins, based on the body weight of an average adult ( $60 \mathrm{~kg}$ body weight). Recommended nutrient intake (RNI) values are shown in table 2. The Committee on Medical Aspects of Food and Nutrition Policy [57], suggested macroalgae consumption of $8 \mathrm{~g}$ per day is a typical daily portion consumed in the Asian cuisine. Considering these references, and the maximum content of $\mathrm{Pb}$ and $\mathrm{Cd}$ detected in D. flabellata (8.8 $\mathrm{mg} \mathrm{kg}^{-1}$ and $4.33 \mathrm{mg} \mathrm{kg}^{-1} \mathrm{~d} . \mathrm{w}$, respectively), these macroalgae would 
Citation: Tenorio-Rodríguez PA, Méndez-Rodríguez LC, Serviere-Zaragoza E, O’Hara T, Zenteno-Savín T (2013) Antioxidant Substances and Trace Element Content in Macroalgae from a Subtropical Lagoon in the West Coast of the Baja California Peninsula. Vitam Trace Elem 2:108.

Page 4 of 5

contribute $33 \% \mathrm{~Pb}$ and $49 \% \mathrm{Cd}$ of the recommended daily dose by $\mathrm{FAO} / \mathrm{WHO}$. These contributions from a single macroalgae species could be considered to be high. However, trace element levels in all the macroalgae species analyzed in this study are below the permissible limits established by FAO/WHO.

The trace element and antioxidant content found in eight species of macroalgae in Bahia Magdalena, Baja California Sur, suggest that these species are safe and potentially exploitable for human consumption, and that macroalgae could be an alternative source of antioxidants and trace elements to help meet the recommended daily intake of some trace elements and vitamin C. However, in brown macroalgae, the content of elements, such as $\mathrm{Cd}$ and $\mathrm{Pb}$ should be monitored to ensure chemical safety.

\section{Acknowledgments}

Authors acknowledge financial support from CIBNOR (PC2.0, PC0.10), and the assistance of $\mathrm{H}$. Berviera Leon and J. Angulo Calvillo in the field, A. Mazariegos in macroalgae identification, and N. Olguín-Monroy, B. Acosta, G. Peña Armenta, O. Lugo-Lugo and J.M. Castellini in quantitative analysis.

\section{References}

1. Chapman VJ, Chapman DJ (1980) Seaweeds and their uses. (3 $3^{\text {rd }}$ edition), London \& New York: Chapman \& Hall, USA.

2. Rupérez P (2002) Mineral content of edible marine seaweeds. Food Chem 79: 23-26.

3. MacArtain P, Gill Cl, Brooks M, Campbell R, Rowland IR (2007) Nutritional value of edible seaweeds. Nutr Rev 65: 535-543.

4. Darcy-Vrillon B (1993) Nutritional aspects of the enveloping use of marine macro algae for the human industry. Int J Food Sci Nutr 44: 23-35.

5. McDermid KJ, Stuercke B (2003) Nutritional composition of edible Hawaiian seaweeds. J Appl Phycol 15: 513-524.

6. Mamatha BS, Namitha KK, Senthil A, Smitha J, Ravishankar GA (2007) Studies on use of Enteromorpha in snack food. Food Chem 101: 1707-1713.

7. Halliwell B, Gutteridge JMC (1985) Free Radicals in Biology and Medicine. Clarendon Press, New York, USA

8. Radák Z, Chung HY, Goto S (2005) Exercise and hormesis: oxidative stressrelated adaptation for successful aging. Biogerontology 6: 71-75.

9. Valko M, Leibfritz D, Moncol J, Cronin MT, Mazur M, et al. (2007) Free radicals and antioxidants in normal physiological functions and human disease. Int $J$ Biochem Cell Biol 1: 44-84.

10. Vertuani S, Angusti A, Manfredini S (2004) The antioxidants and proantioxidants network: an overview. Curr Pharm Des 10: 1677-1694.

11. Powell SR (2000) The antioxidant properties of zinc. J Nutr 130: S1447-S1454.

12. Michalak A (2006) Phenolic compounds and their antioxidant activity in plants growing under heavy metal stress. Polish J Environ Stud 15: 523-530.

13. Gharras HE (2009) Polyphenols: Food sources, properties and applications-a review. Int J Food Sci Tech 44: 2512-2518.

14. Bender DA (2003) Vitamin C (ascorbic acid). In: Nutritional Biochemistry of the Vitamins. (2nd edn), Cambridge University Press, UK.

15. Dawczynski C, Schubert R, Jahreis G (2007) Amino acids, fatty acids, and dietary fibre in edible seaweed products. Food Chem 103: 891-899.

16. Cornish ML, Garbary DJ (2010) Antioxidants from macroalgae: potential applications in human health and nutrition. Algae 25.

17. Mabeau S, Fleurence $J$ (1993) Seaweed in food products: Biochemical and nutritional aspects. Trends Food Sci Technol 4: 103-107.

18. Matanjun P, Mohamed S, Mustapha NM, Muhammad K (2009) Nutrient content of tropical edible seaweeds, Eucheuma cottonii, Caulerpa lentillifera and Sargassum polycystum. J Appl Phycol 21: 1-6.

19. Zaytsev O, Cervantes-Duarte R, Montante O, Gallegos-García A (2003) Coastal upwelling activity on the Pacific shelf of the Baja California Peninsula. J Oceanogr 59: 489-502.

20. Knott KK, Schenk P, Beyerlein S, Boyd D, Ylitalo GM, et al. (2011) Blood-based biomarkers of selenium and thyroid status indicate possible adverse biological effects of mercury and polychlorinated biphenyls in Southern Beaufort Sea polar bears. Environ Res 111: 1124-1136.

21. Barrera-García A, O’Hara T, Galván-Magaña F, Méndez-Rodríguez LC Castellini JM, et al. (2012) Oxidative stress indicators and trace elements in the blue shark (Prionace glauca) off the east coast of the Mexican Pacific Ocean. Comp Biochem Physiol C Toxicol pharmacol 156: 59-66.

22. Carvajal M, Martinez MR, Martinez-Sanchez F, Alcaraz CF (1997) Effect of ascorbic acid addition to peppers on paprika quality. J Sci Food Agric 75: 442446.

23. Ledezma-Gairaud M (2004) Validación del método: determinación de Vitamina $\mathrm{C}$ total por cromatografía liquida de alta resolución. Tecnología en Marcha 17: $15-23$

24. Singleton VL, Rossi JA (1965) Colorimetry of total phenolics with phosphomolybdic-phosphotungstic acid reagents. Am J Enol Vitic 16: 144-158.

25. Soriano-Melgar LAA, Alcaraz-Meléndez L, Méndez-Rodríguez LC, Puente ME, Rivera-Cabrear F, et al. (2012) Antioxidant and trace element content of damiana (Turnera diffusa Willd) under wild and cultivated conditions in semiarid zones. Ind Crops Prod 37: 321-327.

26. Zar JH (1999) Biostatistical Analysis. (4th edn), Prentice Hall, Upper Saddle River, NJ, USA.

27. Girodon F, Blache D, Monget AL, Lombart M, Brunet-Lecompte P, et al. (1997) Effect of a two-year supplementation with low doses of antioxidant vitamins and/or minerals in elderly subjects on levels of nutrients and antioxidan defense parameters. J Am Coll Nutr 16: 357-365.

28. Opara EC, Rockway SW (2006) Antioxidants and micronutrients. Dis Mon 52 151-163.

29. Gibney MJ, Margetts BM, Kearney JM, Arab L (2004) Public Health Nutrition Wiley, USA.

30. Jarup L (2003) Hazards of heavy metal contamination. Br Med Bull 68: 167182.

31. Almela C, Algora S, Benito V, Clemente MJ, Devesa V, et al. (2002) Heavy metal, total arsenic, and inorganic arsenic contents of algae food products. $J$ Agric Food Chem 50: 918-923.

32. van Netten C, Hoption Cann SA, Morley DR, van Netten JP (2000) Elemental and radioactive analysis of commercially available seaweed. Sci Total Environ 255: 169-175

33. Kim SY, Sidharthan M, Yoo YH, Lim CY, Joo JH, et al. (2003) Accumulation of heavy metals in Korean marine seaweeds. Algae 18: 349-354.

34. Besada V, Andrade JM, Schultze F, González JJ (2009) Heavy metals in edible seaweeds commercialised for human consumption. J Mar Syt 75: 305-313.

35. Almela C, Clemente MJ, Vélez D, Montoro R (2006) Total arsenic, inorganic arsenic, lead and cadmium contents in edible seaweed sold in Spain. Food Chem Toxicol 44: 1901-1908.

36. Mok JS, Park HY, Kim JH (2005) Trace metal contents and safety evaluation of major edible seaweeds from Korean Coast. Journal of The Korean Society of Food Science and Nutrition 34: 1464-1470.

37. Mohamed AE, Rashed MN, Mofty A (2003) Assessment of essential and toxic elements in some kinds of vegetables. Ecotoxicol Environ Saf 55: 251-260.

38. Lawal AO, Audu AA (2011) Analysis of heavy metals found in vegetables from some cultivated irrigated gardens in the Kano metropolis, Nigeria. J Environ Chem Ecotoxicol 3: 142-148.

39. Muñoz-Barbosa A, Gutiérrez-Galindo EA, Segovia-Zavala JA, DelgadilloHinojosa F, Sandoval-Salazar G (2004) Trace metal enrichment in surface sediments of the northwest coast of Baja California, Mexico. Mar Pollut Bull 48: 596-603.

40. Rodríguez-Meza D, Choumiline E, Méndez L, Acosta-VargasB, Sapozhnikov D (2007) Chemical composition of sediments and macroalgae Magdalena lagoon complex of venus. In: Funes R, Gómez J, Palomares R (Eds) Ecological studies in Magdalena Bay National Polytechnic Institute.

41. McDermid KJ, Stuercke B, Balazs GH (2007) Nutritional composition of marine plants in the diet of the green sea turtle (Chelonia mydas) in the Hawaiian Islands. Bull Mar Sci 81: 55-71.

42. Anantharaman P, Devi GK, Manivannan K, Balasubramanian 
Citation: Tenorio-Rodríguez PA, Méndez-Rodríguez LC, Serviere-Zaragoza E, O’Hara T, Zenteno-Savín T (2013) Antioxidant Substances and Trace Element Content in Macroalgae from a Subtropical Lagoon in the West Coast of the Baja California Peninsula. Vitam Trace Elem 2:108.

Vitamin-C content of some marine macroalgae from Gulf of Mannar Marine Biosphere Reserve, south east coast of India. Plant Archives 11: 343-346.

43. Hernández-Carmona G, Carrillo-Domínguez S, Arvizu-Higuera DL, RodríguezMontesinos YE, Murillo-Álvarez JI, et al. (2009) Monthly variation in the chemical composition of Eisenia arborea J.E. Areschoug. J Appl Phycol 21: 607-616.

44. Celikler S, Vatan O, Yildiz G, Bilaloglu R (2009) Evaluation of antioxidative, genotoxic and antigenotoxic potency of Codium tomentosum Stackhouse ethanolic extract in human lymphocytes in vitro. Food Chem Toxicol 47: 796801

45. Vanderslice JT, Higgs DJ, Hayes JM, Block G (1990) Ascorbic acid and dehydroascorbicacid content of foods-as-eaten. J Food Compost Anal 3: 105 118.

46. Lim YY, Lim TT, Tee JJ (2007) Antioxidant properties of several tropical fruits: A comparative study. Food Chem 103: 1003-1008.

47. Susanna Cunningham- Rundles (1993) Nutrient modulation of the immune response. CRC PressINC.

48. Wintergerst ES, Maggini S, Hornig DH (2006) Immune-enhancing role of vitamin $\mathrm{C}$ and zinc and effect on clinical conditions. Ann Nutr Metab 50: 85-94.

49. Jiménez-Escrig A, Jiménez-Jiménez I, Pulido R, Saura-Calixto F (2001) Antioxidant activity of fresh and processed edible seaweeds. J Sci Food Agric 81: $530-534$
50. Kamiya M, Nishio T, Yokoyama A, Yatsuya K, Nishigaki T, et al. (2010) Seasonal variation of phlorotannin in sargassacean species from the coast of the Sea of Japan. Phycol Res 58: 53-61.

51. Erdman JW, Balentine D, Arab L, Beecher G, Dwyer JT, et al. (2007) Flavonoids and heart health: proceedings of the ILSI North America Flavonoids Workshop, May 31-June 1, 2005, Washington, DC. J Nutr 137: S718-S737.

52. Williamson G, Manach C (2005) Bioavailability and bioefficacy of polyphenols in humans. II. Review of 93 intervention studies. Am J Clin Nutr 81: S243-S255.

53. Brat $P$, Georgé S, Bellamy A, Du Chaffaut L, Scalbert A, et al. (2006) Daily polyphenol intake in France from fruit and vegetables. J Nutr 136: 2368-2373.

54. http://www.who.int/nutrition/publications/micronutrients/9241546123/en/index. html.

55. Joint FAO/WHO (1999) Expert committee on food additives. Summary and conclusions, 53rd meeting, Rome, 1-10 June.

56. Joint FAO/WHO (1998) Expert consultation on human vitamin and mineral requirements, Bangkok Thailand, 21-30 September.

57. (1991) Dietary Reference Values for Food Energy and Nutrients for the United Kingdom Report of the Panel on Dietary Reference Values of the Committee on Medical Aspects of Food Policy. Rep Health Soc Subj (Lond) 41: 1-210. 